\title{
Is Southern Africa Ready for Regional Monetary Integration?
}

\author{
Carolyn Jenkins \\ and \\ Lynne Thomas
}

\author{
Novemeber 1996 \\ Centre for the Study of African Economies \\ University of Oxford \\ 21 Winchester Road \\ Oxford OX2 6NA
}

Carolyn Jenkins is at the Centre for the Study of African Economies, University of Oxford, Centre for Research into Economics and Finance in South Africa, and the London School of Economics

Lynne Thomas is at the Centre for Research into Economics and Finance in South Africa, and the London School of Economics

\begin{abstract}
This paper examines whether Southern Africa is ready for regional monetary integration. It reviews the lessons from theory and experience, focusing on (i) the problem of spillover effects and the implications for policy coordination; (ii) the appropriate conditions for exchange-rate coordination, which is necessarily implied by monetary policy coordination; and (iii) issues surrounding convergence of per capita income and convergence of macroeconomic stability indicators. The paper considers macroeconomic policy and convergence in SADC. It provides summary information of the macroeconomic policies currently pursued in SADC, and highlights the areas of key policy weaknesses. The extent of convergence of per capita income in SADC is measured using the two most common methods. From this analysis there is no evidence of convergence in the SADC countries (if anything there is a slight divergence) but a pattern of convergence amongst the SACU countries is evident. The paper examines whether this result can be explained by divergence in policy variables. Using the Maastricht criteria variables (where data are available) as a starting point, the paper demonstrates that there is significant divergence of key policy and stability indicators among SADC as a whole, but there is a degree of convergence among a sub-sample consisting of the CMA countries, Botswana and Mauritius. The paper concludes that the lack of convergence of the economies over time and the significant divergence of policy and stability indicators suggests that Southern Africa is not yet ready for regional monetary integration.
\end{abstract}




\section{1) Introduction ${ }^{1}$}

International interest in economic integration is spawning new regional initiatives in every continent. Africa does not lag the world in setting up these arrangements; in fact the world's oldest customs union exists in Southern Africa, and the list of both past and present multilateral economic agreements is probably longer than that of any other continent. Africa's problem lies in setting up regional initiatives where both benefits for members and penalties for non-compliance are sufficiently substantial to ensure continuing cooperation. There are successful examples, notably the Southern African Customs Union and the (Rand) Common Monetary Area, and some partially successful arrangements in Francophone Africa, but Africa's record of creating workable regional frameworks is poor. African policy-makers are nevertheless still searching for broader economic cooperation as a solution to small markets and generally weak economies. South Africa's participation in an economic community centred on the Southern African Development Community (SADC), which it dominated even while it was excluded, is seen as the opportunity with greatest potential for success.

It should not be assumed that because regional economic integration is fashionable, it is necessarily an appropriate strategy to pursue. Economic research is building some consensus on the conditions under which policy coordination and/or trade blocs may be optimal. Many of the most recent developments in the theoretical (and empirical) literature on macroeconomic policy coordination applies to developed economies. However, there are important applications to be made to developing regions.

This paper begins by reviewing the theoretical and empirical literature on macroeconomic policy coordination. The conclusion drawn is that some degree of macroeconomic convergence is necessary for effective policy coordination. The paper goes on to consider macroeconomic policy and convergence in SADC.

\footnotetext{
${ }^{1}$ This paper is based on background work carried out as part of a larger macroeconomic policy project for the SADC Finance and Investment Sector Coordinating Unit in the South African Department of Finance.
} 


\section{2) Lessons from Theory and Experience}

This review of the literature is long, but there are several issues that are critical when discussing the readiness of a group of countries for macroeconomic policy coordination. In essence, the argument is as follows. The desire to coordinate policy arises from three sources. Firstly, changes in macroeconomic policy in one country have spillover effects on others, possibly generating a need for adjustment which would not otherwise have arisen. Secondly, there is a desire to avoid beggar-thy-neighbour devaluations in the pursuit of high employment. Thirdly, the theoretical prediction that poorer countries should catch up with richer ones (because, for example, they can take advantage of existing technological developments without having to develop their own) is weakly supported in groups of countries where cooperation is occurring: there is a growing consensus that 'convergence clubs' exist, where countries with a lower GNP per capita grow more rapidly because they are members of a trade group, or because domestic policy gains credibility by being tied to the domestic policy of a country with a better economic reputation. However, there are also costs attached to economic policy coordination: primarily a loss of the use of policy instruments for domestic stabilisation (in political terms, a 'loss of sovereignty'). For policy coordination to create a net gain, it is necessary that there be some degree of 'convergence' (explained below) between the participating countries, and that either they fulfil certain criteria in terms of both the domestic policy stance and the structure of domestic institutions, or there is a supranational body which has sufficient authority to enforce compliance. The international experience is mixed, both in terms of feasibility of cooperation, and in terms of effectiveness of regional arrangements.

2a) Macroeconomic Policy Coordination and the Problems of Spillover Effects

This section reviews the desirability and form of multilateral macroeconomic policy coordination. 
World economies are linked in such a way that monetary and budget policies adopted in one country affect the economic performance of other countries. Much of the current literature on international macroeconomics deals with the international transmission of national macroeconomic policies (see Persson and Tabellini, 1995, for references). Clearly inefficiencies (and worse) are possible: governments choose policies to maximise domestic objectives and ignore the externalities imposed on other countries, possibly generating sub-optimal equilibria. The current concern with international policy coordination (or cooperation) stems from a felt need to take into account both domestic policy incentives and international strategic considerations. This at least is one motivation for the concern within the SADC over macroeconomic policy coordination. South Africa's economic dominance means that changes in its domestic economic policy may have large spillover effects on its neighbours. Moreover, some countries have been adversely affected by cross border effects of uncoordinated structural adjustment programmes in the region.

Even within a single country, there are often difficulties with policy coordination, not least because different agents have responsibility for oversight. In developed countries, fiscal policy is the collective decision of politically motivated representatives, while monetary policy is implemented by a single-minded institution, with a greater or lesser degree of distance from the direct political process. In African countries, fiscal policy may be determined by collective decision-making in parliament, although sometimes it is the preserve of a centralised decision-making body consisting of the President and Ministers of economic departments. Monetary policy is frequently subservient to the dictates of financing the budget deficit. Furthermore, some autonomy in domestic economic policy-making may be lost to the international financial institutions. In the latter case, the IFIs usually also have objectives limited to the domestic economy, and ignore the externalities which structural adjustment programmes impose on other countries.

Changes in domestic fiscal policy are transferred to other countries (I) through changes in the terms of trade; (ii) where capital is internationally mobile, through changes in the 
after-tax return to international capital in different localities; and (iii) through changes in the demand for imports. Internationally there are no examples of tight fiscal policy coordination outside of federal structures (Persson and Tabellini, 1995:3). Cooperation in fiscal policy would imply some harmonisation of tax rates and of expenditures on subsidies. However, governments with private agendas, like re-election or a particular ideology, would find it in their interests not to cooperate, since this reduces their room for manoeuvre. Only when there are long-term relationships between countries, which create reputational and institutional incentives to maintain the relationship, can some policy coordination be sustained. If self-enforcement is insufficient, then international structures (agencies of restraint) are necessary, which have authority to enforce cooperation. Alternatively, in situations where one country is dominant, lump sum compensating payments by the dominant country may be necessary to hold the participating countries together.

Changes in domestic monetary policy are transmitted to other countries through changes in interest rates and changes in the real exchange rate. Cooperation will reduce the inefficiencies which arise when there are conflicts over stabilisation policies or growth targets. A cooperative regime also produces better responses to supply shocks or relative shocks in aggregate demand. However, monetary policy coordination may be counterproductive if governments lack credibility with the private sector, i.e., gains from cooperation are only ensured when the appropriate domestic institutions are in place (Rogoff, 1985:200;210). If domestic solutions to credibility problems cannot be found, countries have to resort to international arrangements. Examples include supranational authorities like the Bretton Woods institutions, in the case of developing countries, or the European Monetary System.

Monetary cooperation usually takes the form of a fixed exchange-rate regime, where the smaller country makes a one-sided commitment to a specific monetary policy 'reaction function', while the dominant country chooses its monetary policy freely. Where shocks affect the two countries symmetrically, there is no need for any cooperative agreement - the one-sided peg is sufficient for a cooperative outcome (for 
example, the Austrian schilling pegged to the D-mark). If shocks affect countries asymmetrically, then they strain the whole mechanism, especially when they affect the central country (for example, the US and the Vietnam War under the Bretton Woods system, or German unification under the EMS). The stronger country must not only take the smaller country into account, but must give it extra weight and a contract is necessary whereby the central-currency country commits itself to pursuing restrictive monetary policy when it suffers a negative external shock, and the periphery country commits itself to a fixed exchange rate (Persson and Tabellini, 1995:42). However, usually only the smaller country is prepared to commit to such a contract. A fixed exchange-rate contract is therefore only feasible in the case of extreme symmetry (and, possibly, extreme asymmetry, although the literature rarely deals with this case). Incentives to deviate from an exchange-rate peg are only small if $(\mathrm{I})$ the central country has a lot of credibility; (ii) shocks are not asymmetric; and (iii) macroeconomic development in the participating countries is relatively parallel. These issues are dealt with in greater detail below.

Before examining more closely the economic issues of policy coordination, note that there are important political issues to be considered. To a very great extent, a nation has the ability to achieve its economic goals by itself. Although the levels of demand, inflation and interest rates in one country affect economies elsewhere, a country can manage its own monetary and fiscal policies to offset many of the potential influences from abroad. There is a serious risk that economic summits and ministerial meetings can slow down the taking of painful decisions to make appropriate changes to domestic policies. This occurs either because politicians feel that they can escape their responsibilities by blaming poor domestic performance on policies pursued abroad, or because they hope that coordinated foreign action will make domestic changes unnecessary, or because their actions are, in fact, bound by international agreements. Moreover, the attempt to pursue coordination in a wide range of macroeconomic policies is likely, even among developed countries, to result in disagreements that reduce the prospects for cooperation in those more limited areas of trade, defence and foreign assistance where international cooperation is actually necessary (Feldstein, 
1988:3). The collapse of, or non-compliance with, international agreements can lead to recriminations, souring foreign relations. It is better not to set up a policy union which is destined to fail.

In summary, policy unions are difficult to maintain, particularly if member countries respond asymmetrically to external shocks. Where there are long-term relationships that are mutually desirable then some policy coordination may be sustained, but the wider the range of policy variables tied by international treaties, the smaller the likelihood of compliance.

\section{2b) Exchange-Rate Coordination}

There is consensus in economic theory that fixed exchange rates are less appropriate for countries dependent on the inflation tax; without factor mobility; subject to rigidities, so that shocks take years to work their way through the economy; and where shocks for core and peripheral countries are asymmetric. The most extreme form of exchange-rate coordination is the formation of a currency union. Adopting a common currency means that a country cannot (I) devalue/revalue on its own, or (ii) control the quantity of money (De Grauwe, 1992).

The reasons for pegging are: (I) to reduce the costs associated with unpredictable volatility, both short-term and long-term; (ii) to restrain domestic inflationary pressures; (iii) to import credibility from the low-inflation country; and (iv) to anchor price inflation for internationally traded goods, providing a guide for private-sector inflation expectations.

The costs of pegging include: (I) the loss of the exchange rate as a stabilisation instrument; (ii) the loss of control of the domestic money supply, and, consequently, loss of monetary instruments for stabilisation; (iii) increasing the fiscal burden of higher inflation countries by reducing seigniorage revenue if disinflation is necessary (Gros and Vandille, 1995); (iv) the threat (and reality) of speculative attacks; and (v) if a 
common currency is adopted, the potential for conflict over, for example, the distribution of seigniorage, common versus domestic stabilisation requirements, etc..

Since the breakdown of the Bretton Woods system, very few fixed-rate regimes have actually remained intact, not only because of the costs of pegging, but because reserves are dwarfed by the size of short-term capital flows, and giant capital markets magnify any weakness in a country's commitment to a fixed rate, leaving little room for manoeuvre (Obstfeld and Rogoff, 1995:94).

European efforts to peg exchange rates within narrow bands have ended in spectacular debacles. As European and Mexican experiences have shown, a fixed exchange rate is very costly for a government to maintain, when its promises not to devalue lack credibility. At the same time, developing and maintaining credibility has become increasingly difficult, as the 1994-95 Mexican and 1996 South African experiences showed.

Certain conditions must be fulfilled if there is to be a net gain from fixing exchange rates. One relevant area of theory is that of optimal currency areas (OCAs), although this is criticised by some as 'murky and unsatisfactory' (Buiter, 1995:1). Nevertheless, the key insight of this body of theory is that countries or regions which experience a high diversity in output and employment growth need considerable labour market flexibility if they want to form a monetary union and avoid major adjustment problems.

Consider the following example. If there are two countries in a monetary union and an external shock shifts demand from one country's goods to the other's, the first country will run a current-account deficit and the second a surplus. In order to adjust, it is necessary for labour to move from the deficit country to the surplus country, or for real wages to fall in the deficit country and to rise in the surplus country. If neither, then the surplus country must allow inflation to occur. Resisting this means that the currentaccount surplus will persist, and that inflationary pressures will therefore persist. By 
contrast, the deficit country will have unemployment. If it cannot devalue, it must deflate to eliminate the deficit, but this will worsen the unemployment problem.

An alternative solution would be for the surplus country to increase taxation, and transfer the revenue to the deficit country. The deficit will then persist, but will be financed by the surplus country. These transfers between countries are known as 'regional policy'. This is in effect what happens within one national unit (country), where transfers occur from more prosperous regions to ailing regions via the fiscus.

Countries with a low degree of flexibility in the labour market given the level of real divergence do not form an OCA, and are better advised to maintain some degree of exchange-rate flexibility, even if this carries economic costs.

Nevertheless, credibility gains are possible for a small country, if it pegs to the currency of a large neighbour with a credible anti-inflationary policy as has occurred in the Common (Rand) Monetary Area. This may suggest adopting the (stable) currency of a larger country under a currency board arrangement, as in, for example, Estonia (Burdekin and Langdana, 1995:24,25), or creating a supranational authority with currency boards.

In summary, monetary union is optimal if one - or a combination - of several conditions is fulfilled: there is wage flexibility; labour is mobile between countries; politically easy transfers are possible; and countries react similarly to shocks. A degree of real economic convergence (explained immediately below) is necessary for exchange rate coordination. The consensus seems to be that for groups of countries which are not OCAs, maintaining exchange-rate flexibility is best, while at the same time introducing/preserving institutional constraints on expansionary policy (like guaranteeing the independence of the central bank, and/or reforming monetary institutions to focus on restraining domestic inflation, see the recommendations for Southern Africa of Harvey and Hudson, 1993). In other words, the exchange rate 
becomes an indicator and not the central target for monetary policy (Irwin and Vines, 1995:18; Obstfeld and Rogoff, 1995:74).

\section{2c) Convergence}

The convergence literature is confused and confusing. There appear to be different issues involved, and no consensus on any particular issue! For example, the literature refers to, but does not self-consciously distinguish between, convergence in two different contexts:

Convergence in GDP per capita (i.e., a tendency for equalisation of income)

This arises out of the prediction of neoclassical growth theory that poor economies might 'catch up' with richer ones. If countries are converging, there would be a negative relationship between income per head at the beginning of some time period and subsequent rates of growth (in income per head).

Most empirical studies testing the convergence hypothesis find no convergence occurring among all countries in the world, or even among a very large sub-sample of the world's economies (Romer, 1986). In fact, many poorer countries have been experiencing negative per capita growth, so that the gap between rich and poor countries has been increasing.

However, within smaller groups of countries (regions), like the OECD countries, or the US states, or Japanese prefectures, there is evidence of convergence (Barro and Sala-IMartin, 1991; Dowrick and Nguyen, 1989). The contrasting evidence has given rise to two related hypotheses:

Convergence Clubs, which are a subset of countries for which convergence applies (Baumol et al (eds), 1994), suggested as being countries with similar initial human capital endowments. Members of the 'club' which are only moderately backward are 
able to take advantage of technological improvements in front-runners, and catch up. An alternative version of this is that all countries which are open and integrated in the world economy are members of the 'convergence club' (Sachs and Warner, 1995:41). Ben-David (1995) also argues that trade-based groups show higher convergence than randomly created groups.

Conditional Convergence, where each country has its own long-run per capita income, and grows more rapidly the greater the gap between initial income per head and its own long-run income per head (which is proxied by certain structural variables, like initial human capital endowments) (Barro and Sala-I-Martin, 1991; 1992; 1995). Other structural variables causing substantially different steady states include disparities in savings rates, fertility, and the available technology (Barro et al, 1995:103). Sachs and Warner argue that their hypothesis (that trade liberalisation creates the right conditions for convergence) can also be cast as a conditional convergence hypothesis: apparent differences in long-run income levels are due to differences in policies regarding economic integration (1995:41).

\section{3) Convergence in Macroeconomic Stability Indicators}

There is a debate as to whether this is a precondition for or a result of a fixed exchange rate regime. The literature deals almost exclusively with the $\mathrm{EU}$ and the conditions that make up the Maastricht criteria for joining the proposed European Monetary Union. As such, these convergence criteria provide a natural starting point for examining the international experience.

Clearly the criteria was envisaged by those who drew up the Maastricht Treaty as a precondition for monetary union in Europe (see Artis, 1992; Healey and Levine, 1993). Article $109 \mathrm{~F}$ of the treaty sets out the following requirements for eligibility: (I) inflation rates must converge close to the average rates achieved by the three countries with lowest inflation; (ii) long-term nominal interest rates on government debt must converge to a level close to the average of those achieved by the three countries with 
lowest inflation; (iii) exchange rates must be stable (within the ERM bands) for two years prior to EMU without any measures to stop the free flow of foreign exchange; (iv) the deficit-to-GDP ratio must not exceed 3 percent; (v) the public debt-to-GDP ratio must not exceed 60 percent. However, it is argued that at least some of these criteria will be automatically satisfied on monetary unification, particularly interest-rate equalisation, and common equilibrium inflation in traded goods (Buiter, 1995:39,16).

The point of the criteria is to minimise the costs to other members of any particular country's joining the EMU. The inflation condition effectively rules out sharp differences in indirect tax policies (Artis, 1992:303). The point of the exchange-rate criterion is to rule out an 'endgame devaluation' (a last devaluation push immediately prior to full integration in order to gain a competitive advantage or to amortise excessive public debt). The inclusion of the interest-rate criterion is a way of taking advantage of the forward-looking character of financial markets, because expectations about future inflation, exchange rates and fiscal policy are embodied in the interest-rate premium. The fiscal criterion is probably the most contentious of all, and a compromise was struck by allowing the 3 percent figure to be interpreted as a guideline. The basic argument for fiscal discipline turns on the analysis of Sargent and Wallace (1981), who argue that fiscal and monetary policy must be consistent: a country with an expansive fiscal policy, and which has a growing government debt-to-GDP ratio, must, at some stage, monetise that debt, making a restrictive monetary policy impossible. The point of the deficit-to-GDP and debt-to-GDP ratios is, therefore, at least in part, to protect other members from having to service part of a country's debt directly or indirectly through European Central Bank monetisation (Buiter, 1995:42). Although fiscal criteria create an inherent contractionary bias in fiscal policy (Bean, 1996:25), countries with a high preference for low inflation are likely to insist on such criteria because they will not want a union with fiscally more expansive economies. On this point alone, a policy union in Southern Africa is demonstrably premature.

There is a lack of consensus as to whether or not exchange rate coordination has helped to foster convergence in macroeconomic stability indicators among EU members 
(reviewed in Bank of England, 1991a). There is also a lack of consensus as to whether monetary integration in Europe is good or bad. Some argue for immediate monetary union (for example, Buiter, 1995). Others argue that the prospects for a single European currency that delivers price stability are not good (Fry, 1991:502). Others prefer to remain agnostic (Allsopp et al, 1995; Begg et al, 1995).

Finally, there is no agreement on the issue of whether convergence in Maastricht criteria (or monetary union) can foster 'catch-up' convergence. The evidence for Europe seems to be mixed, with greater convergence occurring in some periods and not others (Neven and Goyette, 1995). Also it is argued that the costs of achieving forced convergence between West and East Germany have been high, and has required large transfers, and that the Mezzogiorno (Southern Italy) remains relatively poor, despite having complete economic unification, including a common currency, with Northern Italy. In fact, any reduction in income disparities between north and south in Italy appears also to have required large transfers (Begg et al, 1995:10).

In summary, there is a lack of agreement as to the precise nature of the relationship between economic policy coordination and economic convergence. However, in practice, any group of countries contemplating a policy union will require convergence in macroeconomic stability indicators as a prerequisite for admission in order to protect other members from adverse policy spillover effects.

\section{4) Macroeconomic Policy and Convergence in SADC}

There is no a priori expectation of convergence among SADC countries. There is no reason to believe that they form an OCA. Their economies generally and labour markets specifically exhibit rigidities. All are primary commodity exporters, but some are mineral exporters, others rely on tree crops, and others are dependent on other agricultural output to generate foreign exchange; this means that they respond asymmetrically to external price shocks. SADCC was formed in 1980 (with nine of its current twelve members), with the goal of reducing dependence on the dominant 
regional economy, South Africa, which was excluded. As yet there has been no substantive moves towards facilitating intra-regional trade or factor movements. Moreover, there is substantial variation in their current macroeconomic and trade policy frameworks. This point is dealt with in the next sub-section. The extent of general economic convergence follows.

\section{4a) Summary Information of Current Policy Frameworks}

Table 1 contains summary information of macroeconomic policies currently pursued in SADC member states. The qualitative information in the table was collected primarily by interview method. When suitable interviewees were not available, information was derived from EIU quarterly reports. Quantitative data are calculated from published statistics. There are several points to be noted from Table 1:

- Performance indicators at the top of the table diverge considerably, with very large ranges for the variables in 1993/4, even when Angola, which was still experiencing civil war, is excluded.

- Nearly two-thirds of SADC countries are undergoing structural adjustment with funding from the World Bank and/or IMF, and many of these programmes have been in place for about a decade.

- Aid dependence is high in around half of SADC countries, as evidenced by the large disparities between the savings and investment ratios coupled with persistent government deficits and, the external counterpart to this, the large proportion of imports financed by aid.

- The range of policy variables shows considerable variation in domestic policies: for example, the relative sizes of the budget deficits, the range of real lending rates, and the number of countries which regularly permit overvaluation of their currencies.

- In spite of the fiscal stance in two-thirds of SADC countries being described as 'cautious', only half of SADC members have sustained deficits of less than 6 percent of GDP for more than two years. 
- In very few SADC countries does the central bank have operational independence, even in those countries where this is a constitutional provision.

- In most countries the exchange-control regime has been liberalised considerably - completely in two (non-CMA) countries.

- In less than half of the SADC countries can the degree of financial liberalisation be termed 'moderate to high'.

- In all but Angola and Mozambique the trade regime can, on average, be called liberal, although this does not imply that there are still no substantial barriers to entry in some markets.

- Although political liberalisation is occurring, there is little public debate on economic policy issues, and business confidence is undermined by political uncertainty and by corruption; all but one country report evidence of corruption, in some cases of 'macroeconomic proportions'; the record of prosecuting for corruption is poor.

- Roughly half of SADC members have potential for increased political or economic (or both) instability in the medium term.

From the above, the following weaknesses in policy can be deduced. Most obviously and importantly, on average, the fiscal stance is weak: very few countries manage to keep their deficit-to-GDP ratios below 5 percent. This has important implications for the operation of macroeconomic policy generally. The burden of stabilisation falls on the monetary authorities, and the external debt-to-GDP ratios are high, and, in many cases, rising. A country with an expansive fiscal policy, and which has a growing government debt-to-GDP ratio, must, at some stage, monetise that debt, making a restrictive monetary policy impossible. For countries engaged in structural adjustment programmes, a weak fiscal stance undermines the goals of monetary and financial liberalisation, and, ultimately, the effectiveness of the whole programme. This may explain, at least in part, why those countries with, on average, a tighter fiscal stance, also have, on average, higher GDP growth rates, lower consumer price inflation, lower debt-to-GDP ratios and higher investment-to-GDP ratios (see Table 4 below). Despite a greater degree of market determination of official exchange rates, four countries 
regularly allow overvaluation to occur. The large discrete adjustments cause problems for traders.

Although the adoption of structural adjustment programmes by many of the countries suggests that, in principle, policy variables should converge, there is no evidence that this is the case. This is at least in part because not all countries comply fully with the conditions.

The extent of divergence in policy stance and in indicators of macroeconomic stability would suggest that it is premature to consider policy coordination among SADC members. What is not clear is whether there is an underlying trend towards convergence or divergence in SADC: because the majority of SADC members have adopted donor-sponsored structural adjustment programmes in the past decade, is a greater degree of macroeconomic convergence occurring in the region?

\section{4b) Extent of Macroeconomic Convergence}

Because of the problems attached to measures of convergence, there is no consensus as to which measure is best. Three measures have been calculated below.

The most simple measure is $\sigma$-convergence, when the dispersion of cross-sectional income levels diminishes over time, with dispersion typically measured by the standard deviation of per capita income. In this case it is irrelevant whether a single economy shows convergence; what is important is how the entire cross section behaves. If countries which are initially very different are converging, it is expected that the standard deviation will be growing smaller.

A comparison is made below with the European Union - not because the EU is considered a suitable model, or because the $E U$ is necessarily ready for policy union but so that readers unfamiliar with the methodology have a point of reference for comparison. Since the formation of the Common Market in the 1950s, the standard 
deviation of per capita income of all EU members has been falling as shown in Figure 1 (using data from the Penn World Tables, Mark 5.6). There was some interruption to this trend in 1982-3, when a degree of divergence occurred, but this was subsequently reversed.

The calculations for SADC members are plotted in Figure 2. In contrast to the downward sloping pattern of convergence that is evident in the data for EU countries, the pattern for SADC countries is essentially flat - indicating that no convergence in per capita incomes has occurred over the 30-year period. Indeed, the degree of dispersion was marginally higher at the end of the period than at the beginning which suggests that the countries have, if anything, diverged slightly. The absence of convergence among the SADC countries may be due to several factors, including different responses to the oil and exchange-rate shocks of the 1970s, and different problems with indebtedness, but there are also uniquely domestic policy issues which have promoted or slowed growth.

If, however, the sub-sample of SACU member countries is examined separately, as shown in Figure 3, a strikingly different pattern emerges. Although the intra-SACU dispersion of per capita incomes held roughly constant through the 1960s, it dropped steadily in the 1970s and 1980s. The result of this downward trend was that the dispersion at the end of the period was little more than half what it had been at the beginning - a degree of convergence that slightly exceeds that evident in the EU countries over the same period. It is particularly interesting that neither the oil price shocks of the 1970s nor the gold price shock of 1980 - both of which would have had asymmetric effects on the SACU countries - caused any significant interruption to this pattern of convergence. (The same calculations were also made for the sub-sample of CMA countries, and are almost identical to those of the SACU members, which is not surprising, given that Botswana used the Rand until 1976, and did not allow the real Pula-Rand exchange rate to diverge significantly thereafter.) 
The most common measure of convergence is $\beta$-convergence. This occurs when, in a cross-section regression of (time-averaged) growth rates on initial levels of GDP per capita, the ( $\beta$ )-coefficient on initial levels is negative. The underlying assumption is that each region has a steady-state growth path. A downward-sloping plot of average growth rates on initial GDP will indicate possible $\beta$-convergence: if the hypothesis of convergence is supported by the data, then those countries whose per capita income was below the average for all countries at the beginning of the period should have higher average growth rates subsequently.

Using the data in the Penn World Tables, with 1960 as the initial year, average growth rates for the next thirty years were calculated for each country. This information is plotted in Figure 4 for the EU and in Figure 5 for the SADC countries. The EU plot is included simply as an illustration of a region where the data suggests that $\beta$ convergence has occurred.

In 1960, the poorest country in Europe in per capita income terms was Portugal, whose income per head was 64 percent below the European average in 1960. Portugal grew by an average of 4.8 percent in real terms annually over the next thirty years. On the other hand, Sweden and Britain, with per capita incomes of 45 and 30 percent above the average respectively in 1960, grew most slowly over the decade.

Figure 5 shows that, using this second measure, there is no pattern of convergence among Southern African economies over the period. Almost all of the below-average economies in income per capita terms had below-average growth rates over the period, while Mauritius began best-off in 1960 and grew on average 3 percent each year (in terms of real income per head) over the thirty years which followed.

However, if one looks at the sub-set of SACU countries, there is again a very clear trend of convergence, with initially low-income Botswana and Lesotho converging on Swaziland, Namibia and South Africa, but diverging from Malawi and Tanzania which began with similar levels of income per head. 
$\beta$-convergence and $\sigma$-convergence are interesting for illustration, but do not, even in theory, explain whether poorer countries are catching up with richer ones (Quah, 1995:15). $\beta$-convergence collapses dynamic processes into a single summary statistic, and the assumption that each country has a steady-state growth path is simply not supported by data. There are alternative measures. Time series measures, for example, usually use cointegration techniques to show that convergence occurs when the economy returns to its own steady state equilibrium after a shock (see, for example, Hall et al, 1992). However, these are applied to time-series data for single countries, and omit the cross-sectional issues which are important for understanding 'catch-up'. Panel data techniques on the other hand raise concerns over how to deal with individual (fixed or random) effects - and controlling for these means that persistent differences across countries are left unexplained.

An approach suggested by Quah uses a Markov chain-type methodology to estimate the probability that relatively poorer (richer) countries will raise (lower) their per capita income in the next period and thereby converge. The methodology is described simply in Quah (1992) and more technically in Quah (1995). The analysis is descriptive. It does not explain convergence/divergence but it sheds light on how poorer countries behave relative to richer ones and can show not only whether convergence is occurring, but also whether countries are diverging.

Quah's methodology views the process of convergence as a transition process across a number of possible states. Each country/year GDP per capita relative to the sample average constitutes an observation $\left(\mathrm{y}_{\mathrm{it}}\right)$. Observations are grouped in five states of relative prosperity, State 1 being the poorest $\left(y_{i t}<0.33\right)$; State 2: $0.33 \leq y_{i t}<0.67$; State 3: $0.67 \leq y_{\text {it }}<1$; State 4: $1 \leq y<2$; and State 5 being the richest ${ }_{i k}(y \geq 2)$. The choice of interval is somewhat arbitrary; the criterion is that the initial number of observations belonging to each state must be roughly similar - or at least the differences not too large. The annual progression from one distribution into another can be described by a $5 \times 5$ Markov chain transition matrix, the $(j, k)$ entry of which is the probability that an economy in State $j$ moves to State $k$ in one year. 
The analysis for SADC is recorded in Table 2a. (Data are from Penn World Tables, Mark 5.6). The first column in the table is the total number of observations with starting points in each state. For example, of the 360 observations ( 12 countries $\times 30$ years) 73 began in State 3 (the middle), and of these, 90.4 percent remained in that state the following year; 5.5 percent moved down into State 2 ; and 4.1 percent moved into the State 4. It appears that from State 3 a representative economy is almost certain to remain in that state, but, if it moves, it has a marginally greater chance of falling behind than of moving ahead.

The following can be observed from Table 2a. The dominance of the diagonal elements suggests a high degree of persistence, especially among poorer economies. Persistence is least in the middle group. As would be expected, changes are not spectacular: strictly positive elements are observed only around the diagonal. In the neighbourhood of the main diagonal, the tendency at lower incomes is to become or to remain poorer, while at higher relative incomes per head (State 4), there is a marginally higher chance of upward mobility. This suggests cross-country incomes tending to extremes at both high and low endpoints. This finding is consistent with Quah (1992:431; 1995:22). In other words, it appears that the poor get (or remain) poorer, the rich remain rich, and the middle class 'vanishes'. Table $2 b$, which records the distribution of countries appearing in each of the five states in 1960 and 1989, corroborates this conclusion. There appears to be a limited poverty trap, although upward mobility is possible. Moreover, this illustration of the dynamic process suggests that SADC countries have actually diverged over the 30 years from 1960 .

The procedure was repeated for SACU countries, and the results are reported in Table 3. By contrast with the SADC matrix, and consistent with the findings for SACU using alternative measures, persistence increases as one moves down the diagonal, and then decreases from the middle state towards relatively richer economies. This implies a convergence as observations tend towards a mass point, rather than the divergence that is implied in Table 2. 


\section{4c) Extent of Convergence of Indicators of Macroeconomic Policy and Macro-stability}

Having ascertained that SADC countries have, if anything, diverged in the last twenty years, while the sub-set of countries which are part of a monetary and customs union have converged, it is now necessary to consider whether divergence in policy variables may have contributed to this result. Table 4 is a reproduction of Table 1 above, this time with policy indicators divided into SACU and non-SACU members. There are several points which should be noted:

- Both fiscal and monetary policy stances appear to be more cautious on average among SACU members than non-SACU members, despite all non-SACU members (apart from Angola) currently engaging in structural adjustment under IMF/World Bank sponsorship - and, on average, having done so for nearly a decade.

- There is a greater degree of fiscal convergence among SACU countries, with the range of deficit-to-GDP ratios being much closer to the average in 1993 (and, in fact, throughout the period for which data are recorded).

- There is a greater degree of interest-rate convergence among SACU countries, with all five averaging positive real (lending) interest rates during the 1990s. This is inevitably the result of all but Botswana being members of a currency union, and Botswana's having a deliberate policy of the Pula's edging up marginally against the Rand.

- In almost all non-SACU members the government owns or part-owns at least one of the commercial banks; some, but by no means all, state-owned commercial banks have severe bad-debt problems; and in some countries, but by no means all, banks experience interventions for non-commercial purposes.

- The degree of openness to international trade is, on average, much higher among SACU countries.

In order to examine the policy issue more fully, some of these variables are considered in more detail. The natural starting point are those listed in the Maastricht Treaty as 
criteria for entry into the European Monetary Union: inflation rates (CPI); long-term interest rates (as indicators of inflationary expectations); real exchange rates; the debt ratio; and the ratio of the budget deficit to GDP. This permits international comparison. Furthermore, there is some international consensus as to the appropriate goals for these variables. Because of the different circumstances confronting Southern African countries, it would be useful to examine additional variables, like the premium on the black market exchange rate; and the extent of aid dependence. The problem with many of these variables is the lack of data: there is virtually no information on long-term bond yields; data on interest rates and black market exchange-rate premia are patchy; and many of the published series do not go back much before 1980 .

Table 5 records 1990-94 average convergence indicators for those variables where data are available. There is a marked lack of convergence in key policy and stability indicators among SADC countries. Average inflation rates for 1990-1994 vary from 8.6 percent to 870.3 percent, while deficit-to-GDP ratios range from 26.2 percent to Botswana's surpluses (the latest figure available for Angola is 23.7 percent in 1990). This masks a greater degree of convergence among a sub-sample of: CMA members, Botswana and Mauritius. Inflation rates for CMA countries-plus-Botswana range tightly within 1.5 percentage points, and public debt-to-GDP ratios are below 60 percent (with the exception of Lesotho).

One possible reason for the similar inflation rates is the fixing of exchange rates within the CMA, and Botswana's policy of edging the Pula up against the Rand. South Africa's dominance in regional trade makes it difficult for other countries' currencies to diverge for too long. During the 1980s the real rand bilateral rates of all SADC countries, except Tanzania (which traded much less with South Africa) and Mozambique, appear to have been almost constant (Harvey and Jenkins, 1992). Thereafter, the rates for Botswana, Malawi, Mauritius and Zambia remained relatively constant with the rand, while those of other countries depreciated very rapidly. 
Past macroeconomic policy, particularly fiscal policy, pursued in each country may, however, be more important than the fixing of exchange rates. Table 5 suggests that the rate of inflation is more highly correlated with the public debt-to-GDP ratio than recent deficit-to-GDP ratios, possibly implying that the financing of past budget deficits is having an inflationary effect. The discipline imposed on CMA members by the fixed exchange-rate regime may have assisted in maintaining a cautious fiscal policy stance, but Mauritius, which is not a member, was cautious without the discipline, and maintained high growth.

Another candidate for explaining the better growth performance of smaller members of SACU and Mauritius is trade openness which is considerably higher in these countries than, on average, in most non-SACU countries (Table 4). Trade openness is emerging as an explanatory factor in faster economic growth in worldwide empirical studies (Ben-David, 1995; Dollar, 1992; Sachs and Warner, 1995).

Finally, there are factors specific to each country that have nothing to do with regional integration which may have enhanced growth in the smaller SACU countries and retarded it in the others. The explanation of the convergence observed in SACU is the subject of further research.

\section{5) Conclusion}

This paper considers the question of whether Southern Africa is ready for economic integration. The question is prompted by international interest in macroeconomic policy coordination, which in turn stems from the potential for coordination to address the problem of spillover effects from national macroeconomic policies and also from the evidence of the existence of 'convergence clubs', in which countries with a relatively lower per capita income can catch up with other members of the club over time. Economic theory and international experience suggests that for policy coordination to be beneficial, there must be some degree of convergence between countries, and domestic policy and institutions should be effective agencies of restraint on the 
discretionary powers of government (or else there needs to be some supranational institution with powers to enforce compliance).

There is no evidence of convergence of per capita income in SADC members for the period from 1960 to 1990; two measures indicates that there may even have been a slight divergence. However, there has been a marked pattern of convergence amongst the SACU countries, with Botswana and Lesotho 'catching up' with Namibia, South Africa and Swaziland. Moreover, there is significant divergence of key policy and stability indicators across $\mathrm{SADC}$ as a whole, but a degree of convergence in the subset consisting of the CMA countries, Botswana and Mauritius. Two possible underlying factors explaining the 'catch up' effect exhibited by the SACU countries are (i) the similar domestic economic policies, driven in part by the currency union between four of the five members of SACU; and (ii) the relative openness to international trade in the SACU economies, which may form a convergence club. Further research is required to assess the contribution of these two factors, and others, in explaining why convergence appears to have occurred in SACU but not in SADC as a whole.

In conclusion, the apparent lack of convergence of the Southern African economies over time and the current significant divergence of policy and stability indicators suggests that Southern Africa is not yet ready for regional monetary integration. Premature attempts at monetary integration could have political costs, since a failed attempt at monetary integration can generate political disagreements and recriminations that weaken the prospects for coordination in trade, infrastructural development, defence and law enforcement. 


\section{References}

Allsopp, C, G Davies and D Vines (1995), 'Regional macroeconomic policy, fiscal federalism, and European integration', Oxford Review of Economic Policy, 11(2), pp.126-144

Artis, M (1992), 'The Maastricht road to monetary union', Joumal of Common Market Studies 30(3), September, pp.299-309

Bank of England (1991a), 'The exchange rate mechanism of the European Monetary System: a review of the literature', Quarterly Bulletin, 31, pp.73-82

- (1991b), 'European monetary arrangements: convergence and other issues',Quarterly Bulletin, 31, pp.516-520

Barro, $R$ and X Sala-i-Martin (1991), 'Convergence across states and regions', Brookings Papers on Economic Activity, 1:1991, The Brookings Institution, pp.107-158

- (1992), 'Convergence', Journal of Political Economy, 100(2), pp.223-251

- (1995), 'Technological diffusion, convergence and growth', CEPR Discussion Paper Series 1255, October

Barro, R, G Mankiw and X Sala-i-Martin (1995), 'Capital mobility in neo-classical models of growth', American Economic Review, 85(1), pp.103-115

Baumol, W, R Nelson and E Wolff (eds) (1994), Convergence of Productivity: cross-national studies and historical evidence, Oxford University Press

Bean, C (1996), 'Will a single European currency lead to higher unemployment?', CentrePiece, 1, London: Centre for Economic Performance

Begg, I, G Gudgin and D Morris (1995), 'The assessment: regional policy in the European Union', Oxford Review of Economic Policy, 11(2), pp.1-17

Ben-David, D (1995), 'Trade and convergence among countries', CEPR Discussion Paper Series 1126, February

Buiter, W (1995), 'Macroeconomic policy during a transition to monetary union', CEPR Discussion Paper Series 1222, August

Buiter, W et al (1995), 'A centre-periphery model of monetary co-ordination and exchange-rate crises', CEPR Discussion Paper Series 1201, July

Burdekin and Langdana (1995), Confidence, Credibility and Macroeconomic Policy: past, present and future, London: Routledge

De Grauwe, P (1992), The Economics of Monetary Integration, Oxford University Press (1993), 'The political economy of monetary union in Europe', CEPR Discussion Paper Series 842 , September 
- (1995), 'The economics of convergence towards monetary union in Europe', CEPR Discussion Paper Series 1213, July

Dollar, D (1992), 'Outward-oriented developing economies really do grow more rapidly: Evidence from 95 LDCs, 1976-1985', Economic Development and Cultural Change, 40(2): 523544

Dowrick, S and D Nguyen (1989), 'OECD comparative economic growth 1950-1985: catch-up and convergence', American Economic Review, 79(5), pp.1010-1030

Economist Intelligence Unit, Country Reports, various

Feldstein, M (1988), 'Distinguished lecture on economics in government: thinking about international economic coordination', Journal of Economic Perspectives, 2(2), PP.3-13

Fry, M (1991), 'Choosing a money for Europe', Journal of Common Market Studies 29(5), September, pp.481-504

Gros, D and G Vandille (1995), 'Seigniorage and the European Monetary Union: the fiscal implications of price stability and financial market integration', Journal of Common Market Studies 33(2), June, pp.175-196

Hall, S, D Robertson and M Wickens (1992), 'Measuring convergence of the EC economies', Manchester School, 55 Supplement, pp.99-111

Harvey, C and D Hudson (1993), 'Post-apartheid regional financial and monetary cooperation' in B Oden (ed) Southern Africa after Apartheid, Uppsala: Scandinavian Institute of African Studies

Harvey, C and C Jenkins (1992), 'The unorthodox response of the South African economy to changes in macroeconomic policy', IDS discussion paper no. 300

Healey, N and P Levine (1993), 'European Monetary Union or "hard EMS"?', Journal of Regional Policy, 13 3-4/93, pp.371-386

Irwin, G and D Vines (1995), 'The macroeconomics of the Mexican crisis: a simple two-period model', Global Economic Institutions Research Programme Working Paper No.3

Lee, K, H Pesaran and R Smith (1995), 'Growth and convergence: a multicountry empirical analysis of the Solow growth model', mimeo

Maasdorp, G and A Whiteside (1993), Rethinking economic co-operation in Southern Africa: trade and investment, Johannesburg: Konrad-Adenauer Stiftung

McCarthy, C (1992), 'South Africa as a co-operative partner in Southern African trade and investment', paper presented to the conference on regional economic integration, Harare: Southern Africa Foundation for Economic Research 
Neven, D and C Goyette (1995), 'Regional convergence in the European Community', Journal of Common Market Studies 33(1), March, pp.47-65

Obstfeld, M and K Rogoff (1995), 'The mirage of fixed exchange rates', Journal of Economic Perspectives, 9(4), pp.73-96

Persson, T and G Tabellini (1995), 'Double-edged incentives: institutions and policy coordination', CEPR Discussion Paper Series 1141, February

Quah, D (1992), 'Empirical cross-section dynamics in economic growth', European Economic Review, 37, pp.426-434

Quah, D (1995), 'Empirics for economic growth and convergence', CEPR Discussion Paper Series 1140, March

Rogoff, K (1985), 'Can international monetary policy cooperation be counterproductive?' Journal of International Economics, 18, pp.199-217

Romer, P (1986), 'Increasing returns and long run growth', Journal of Political Economy, June, 99, pp. 500-21

Sachs, J and A Warner (1995), "Economic reform and the process of global integration", in W Brainard and G Perry (eds), Brookings Papers on Economic Activity, 1:1995, The Brookings Institution, pp.1-118

Sargent, T and N Wallace (1981), 'Some unpleasant monetarist arithmetic', Quarterly Bulletin of the Reserve Bank of Minneapolis, no.5, pp.1-17

Summers, R and A Heston (1991), 'The Penn World Table (Mark 5): an expanded set of international comparisons, 1950-1988', Quarterly Journal of Economics, May 
Table 1: SADC performance and policy stance summary (numbers in words refer to the number of countries where 'yes' applies

\begin{tabular}{|c|c|c|}
\hline & SADC average (1990-1994) & SADC range (1994) \\
\hline Average GDP growth rates & +2.5 & -10.7 to +17.5 \\
\hline Average inflation rates & $28.8^{\mathrm{a}}$ & 7.3 to 52.5 \\
\hline Average debt-to-GDP (1993, percent) & 121.8 & 13.4 to 450.3 \\
\hline Average investment-to-GDP (percent) & 32.0 & 9.2 to 85.8 \\
\hline Average savings-to-GDP (percent) & 8.8 & -13.7 to +44.4 \\
\hline Number with SAPs & seven $^{\mathrm{b}}$ & - \\
\hline Average length of SAP & 9.4 years & 5 to 15 years \\
\hline SAP broadly on target & four & - \\
\hline Aid greater than 20 percent of imports & five & 1.2 to 113.4 \\
\hline Aid withheld for non-compliance & three & - \\
\hline Aid withheld for political pressure & three & - \\
\hline \multicolumn{3}{|l|}{ Fiscal policy } \\
\hline Cautious fiscal stance ${ }^{c}$ & eight & - \\
\hline Under pressure from IMF/World Bank & seven & - \\
\hline Average deficit-to-GDP ratio (1990-93, percent) ${ }^{d}$ & -6.1 & -22.2 to -0.2 \\
\hline \multicolumn{3}{|l|}{ Monetary policy } \\
\hline Monetary stance: tight & six & - \\
\hline loose/inactive & $\operatorname{six}$ & - \\
\hline Average lending rates positive (1993) & eight & -26.2 to +8.7 \\
\hline Central bank operational independence & three & - \\
\hline Dominant external influence IMF/World Bank & six & - \\
\hline \multicolumn{3}{|l|}{ Exchange rate policy } \\
\hline Official rate market determined & eleven & - \\
\hline Regular overvaluation occurs & four ${ }^{*}$ & - \\
\hline Average premium on parallel rate ( 1989, percent) & $87.9^{\mathrm{a}}$ & 10.0 to 100.2 \\
\hline Dominant external influence IMF/World Bank & $\operatorname{six}$ & - \\
\hline Exchange control regime free & two & - \\
\hline Exchange control regime liberal & nine & 要 \\
\hline \multicolumn{3}{|l|}{ Financial policy } \\
\hline Foreign banks allowed & $\operatorname{ten}^{\prime}$ & - \\
\hline Degree of financial liberalisation modest-high & five & - \\
\hline Government ownership of commercial banks & seven & - \\
\hline \multicolumn{3}{|l|}{ Trade policy } \\
\hline Openness: exports+imports/GDP (percent) & 96.1 & 45.5 tó 155.3 \\
\hline
\end{tabular}


Dominant external influence IMF/World Bank five

\section{Political regime}

Broadly democratic ${ }^{\delta}$

four

Reports of corruption

eleven

against which action taken

two

six

Potential for political instability

Potential for economic instability in medium term

four

Source: Qualitative data collected primarily by interview method and represent the subjective opinions of government employees or economic advisors to national governments. Other information is taken from published sources: World Data, World Bank; International Financinl Statistics, IMF; Country Reports, Economist Intelligence Unit; and national sources.

Notes: a. Angola is excluded because its high inflation/parallel premia would distort the averages

b. Angola negotiating, although negotiations currently in abeyance.

c. 'Cautious fiscal stance' implies no slippages.

d. Budget deficit to GDP, excluding grants.

e. No information available on three countries.

f. No information on two countries.

g. 'Broadly democratic' is wider than multi-party democracy, which is too thin a definition as it excludes those countries where there are reports of harassment of political opposition (including joumalists), where regimes are considered authoritarian, and where the political situation is unresolved. 
Table 2a: Real GDP per capita relative to the SADC average, 1960-1989

States: 5 ; number of observations: 12 countries $\times 30$ years $=360$

\begin{tabular}{cccccc}
\hline $\begin{array}{c}\text { No of obs. } \\
\text { initial state) }\end{array}$ & $0-0.33$ & $0.33-0.67$ & $\begin{array}{c}\text { Final State } \\
0.67-1\end{array}$ & $1-2$ & $2+$ \\
\hline$(67)$ & 0.97 & 0.03 & 0 & 0 & 0 \\
$(84)$ & 0.024 & 0.952 & 0.024 & 0 & 0 \\
$(73)$ & 0 & 0.055 & 0.904 & 0.041 & 0 \\
$(90)$ & 0 & 0 & 0.033 & 0.922 & 0.044 \\
$(46)$ & 0 & 0 & 0 & 0.087 & 0.913 \\
\hline
\end{tabular}

Indicated levels, relative to the SADC average.

Cells are arranged in increasing order, with lowest right-hand corner displaying transitions from rich to rich.

The numbers in parentheses are the number of country/year pairs beginning in a particular cell.

Methodology: from Quah (1995)

Table 2b: Distribution of countries across 'states', 1960 and 1989

\begin{tabular}{cccccccl}
\hline & $0-0.33$ & $0.33-0.67$ & $0.67-1$ & $1-2$ & $2+$ & \\
\hline 1960 & 2 & 2 & 3 & 4 & 1 & $=12$ \\
1989 & 2 & 5 & 0 & 4 & 1 & $=12$ \\
\hline
\end{tabular}

Table 3: Real GDP per capita relative to the SACU average, 1960-1989

States: 5 ; number of observations: 5 countries $\times 30$ years $=150$

\begin{tabular}{cccccc}
\hline $\begin{array}{c}\text { (No of obs. } \\
\text { initial state) }\end{array}$ & $0-0.4$ & $0.4-0.8$ & $0.8-1.2$ & $1.2-1.6$ & $1.6+$ \\
\hline$(24)$ & 0.833 & 0.167 & 0 & 0 & 0 \\
$(29)$ & 0.069 & 0.897 & 0.034 & 0 & 0 \\
$(37)$ & 0 & 0 & 0.838 & 0.162 & 0 \\
$(44)$ & 0 & 0 & 0.159 & 0.795 & 0.045 \\
$(16)$ & 0 & 0 & 0 & 0.25 & 0.75 \\
\hline
\end{tabular}

Indicated levels, relative to the SACU average.

The numbers in parentheses are the number of country/year pairs beginning in a particular cell. 
Table 4: SADC policy stance summary (numbers in words refer to the number of countries where "yes" applies)

\begin{tabular}{|c|c|c|c|}
\hline & SADC (twelve) & non-SACU (seven) & SACU (five) \\
\hline Average GDP growth rates (1990-94) & $2.5 \%$ & $1.8 \%$ & $3.3 \%$ \\
\hline Average inflation rates (1990-94) & $28.8 \%^{2}$ & $42.3 \%^{\mathrm{a}}$ & $12.7 \%$ \\
\hline Average debt-to-GDP (1994) & $121.8 \%$ & $192.3 \%$ & $23.1 \%$ \\
\hline Average investment-to-GDP (1990-93) & $31.8 \%$ & $27.2 \%$ & $35.0 \%$ \\
\hline Number with SAPs & seven ${ }^{b}$ & $\operatorname{six}^{3}$ & one \\
\hline Average length of SAP & 9.4 years & 9.7 years & 8 years \\
\hline SAP broadly on target & four & three & one \\
\hline Aid greater than 20 percent of imports & five & five & zero \\
\hline Aid withheld for non-compliance & three & three & zero \\
\hline Aid withheld for political pressure & three & three & zero \\
\hline \multicolumn{4}{|l|}{ Fiscal policy } \\
\hline Cautious fiscal stance ${ }^{c}$ & eight & three & five \\
\hline Under pressure from IMF/World Bank & seven & $\operatorname{six}$ & one \\
\hline Average deficit-to-GDP ratio $(1990-94)^{d}$ & $-6.1 \%$ & $-7.8 \%$ & $-2.5 \%$ \\
\hline Range of deficit-to-GDP ratios $(1993)^{d}$ & $-22.2 \%$ to $-0.2 \%$ & $-22.2 \%$ to $-0.2 \%$ & $-7.8 \%$ to $-0.5 \%$ \\
\hline \multicolumn{4}{|l|}{ Monetary policy } \\
\hline Monetary stance: tight & $\operatorname{six}$ & two & four \\
\hline loose/inactive & $\operatorname{six}$ & five & one \\
\hline Average lending rates positive (1990-95) & eight & three & five \\
\hline Central bank operational independence & three & two & one \\
\hline Dominant external influence IMF/World Bank & six & six & zero \\
\hline \multicolumn{4}{|l|}{ Exchange rate policy } \\
\hline Official rate market determined & eleven & six & five \\
\hline Regular overvaluation occurs & four ${ }^{2}$ & four ${ }^{2}$ & zero \\
\hline Average premium on parallel rate (1989) & $87.9 \%^{2}$ & $133.7 \% \mathrm{a}^{\mathrm{a}}$ & $19.3 \%$ \\
\hline Dominant external influence IMF/World Bank & $\operatorname{six}$ & $\operatorname{six}$ & zero \\
\hline Exchange control regime free & two & two & zero \\
\hline Exchange control regime liberal & nine & four & five \\
\hline \multicolumn{4}{|l|}{ Financial policy } \\
\hline Degree of financial liberalisation modest-high & five & three & two \\
\hline Government ownership of commercial banks & seven & six & one \\
\hline \multicolumn{4}{|l|}{ Trade policy } \\
\hline Openness: exports+imports/GDP & $90.1 \%$ & $75.4 \%$ & $110.8 \%$ \\
\hline Trade regime liberal & ten & five & five \\
\hline
\end{tabular}


Source: Qualitative data collected primarily by interview method and represent the subjective opinions of government employees or economic advisors to national governments. Other information is taken from published sources: World Data, World Bank; International Financial Statistics, IMF; Country Reports, Economist Intelligence Unit; and national sources.

Notes: a. Angola is excluded because its high inflation/parallel premia would distort the averages

b. Angola negotiating, although negotations currently in abeyance.

c. 'Cautious fiscal stance' implies no slippages.

d. Budget deficit to GDP, excluding grants.

e. No information available on three countries. 
Table 5: Convergence indicators - SADC countries (in percent)

\begin{tabular}{llccc}
\hline & & $\begin{array}{c}\text { Inflation } \\
1990-1994\end{array}$ & $\begin{array}{c}\text { Deficit(Surplus)/GDP } \\
1990-1994\end{array}$ & $\begin{array}{c}\text { Public debt/GDP } \\
\text { most recent }^{2}\end{array}$ \\
\hline \multirow{2}{*}{ non-SACU } & Angola & 870.3 & $\mathrm{n} / \mathrm{a}$ & 117.3 \\
& Malawi & 20.3 & -8.2 & 31.7 \\
& Mauritius & 8.6 & -0.5 & $\mathrm{n} / \mathrm{a}$ \\
& Mozambique & 44.0 & -26.2 & $\mathrm{n} / \mathrm{a}$ \\
& Tanzania & 24.3 & -3.8 & 127.6 \\
Zambia & 129.8 & -3.6 & 70.3 \\
ZACU & 26.5 & -7.5 & 14.0 \\
& Bimbabwe & 12.8 & +6.6 & 67.7 \\
& Lesothwana & 13.6 & -6.4 & 12.3 \\
Namibia & 12.2 & -5.0 & 54.9 \\
South Africa & 12.5 & -4.9 & 19.8 \\
\hline
\end{tabular}

Source: World Data, African Development Indicators, World Bank; Country Reports, Economist Intelligence Unit; Quarterly Bulletin, South African Reserve Bank; Quarterly Economic and Statistical Review, Reserve Bank of Zimbabwe

Notes: a. Botswana 1992; Lesotho 1991; Malawi, 1987; Namibia, 1989; South Africa, 1994; Swaziland, 1993; Zambia, 1987; Zimbabwe, 1994 
Figure 1: Standard deviation of log of per capita income: EU

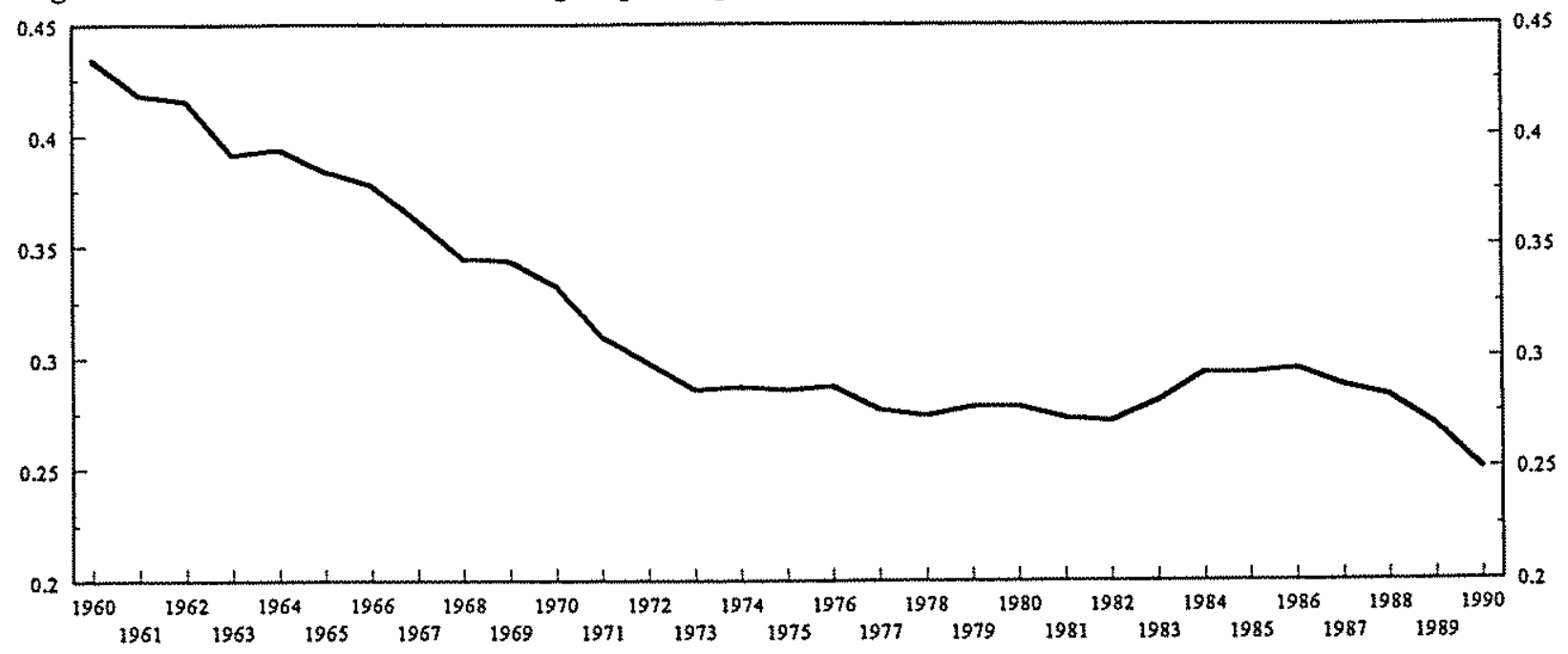

Figure 2: Standard deviation of log of per capita income: SADC

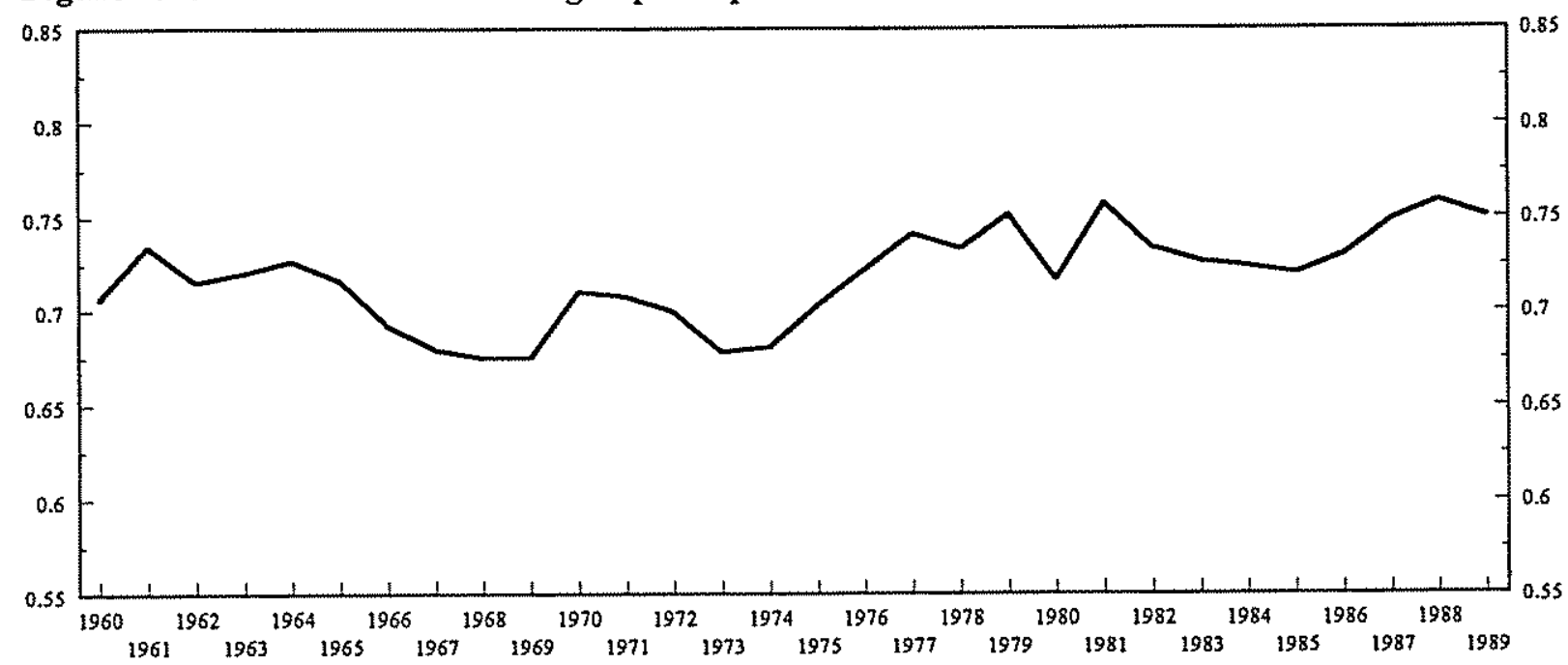

Figure 3: Standard deviation of log of per capita income: SACU

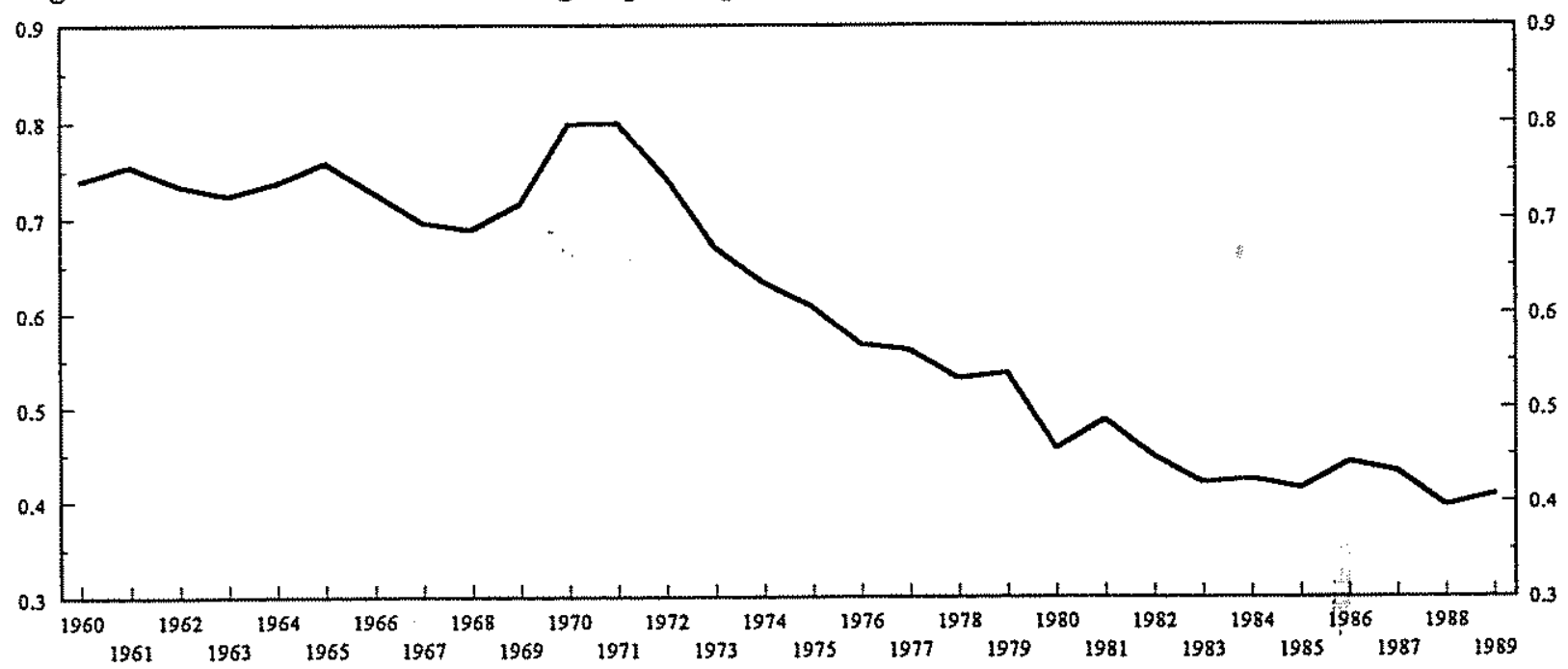


Figure 4: The relationship between per capita income in 1960 and subsequent growth (EU)

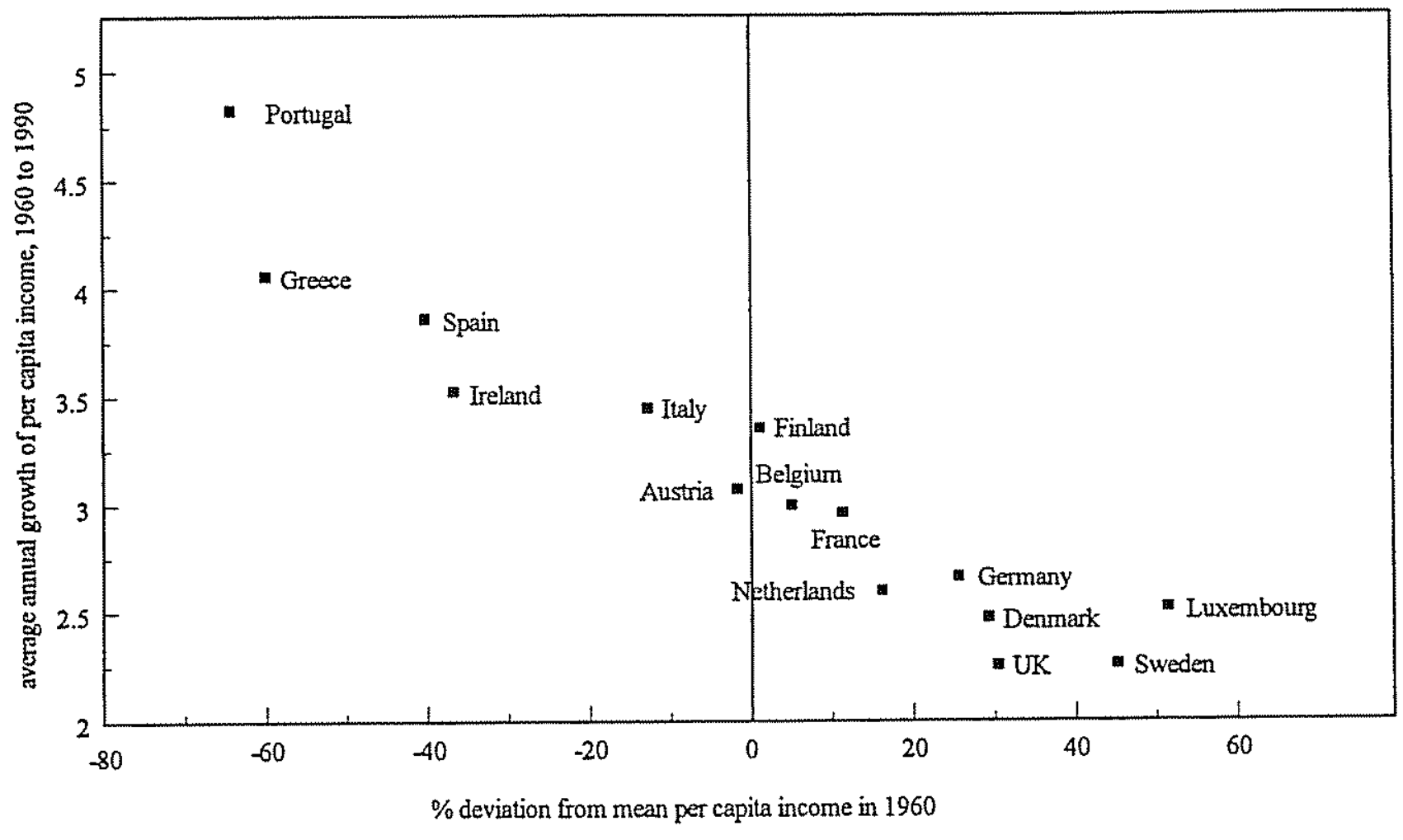

Figure 5: The relationship between per capita income in 1960 and subsequent growth (SADC)

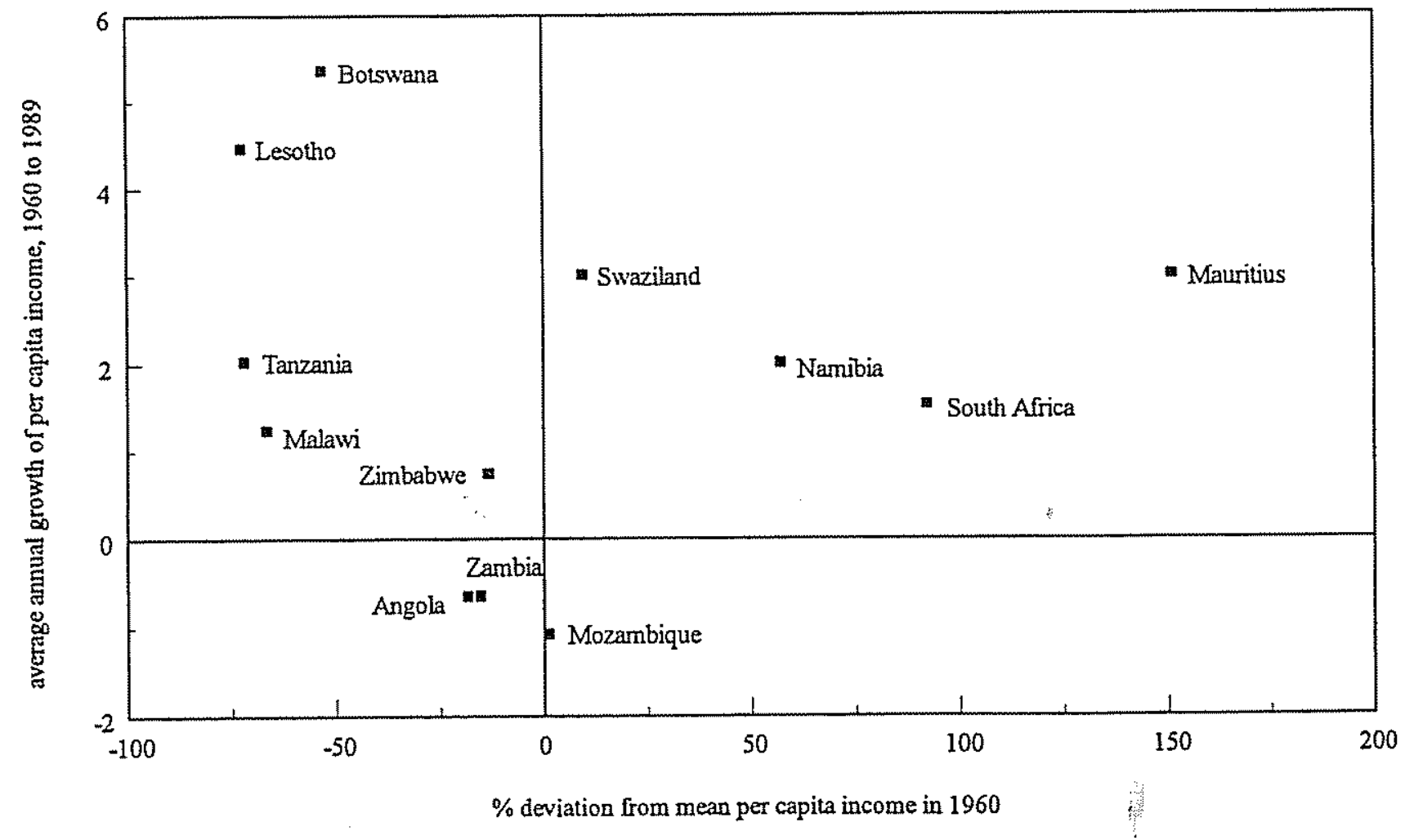

